\title{
Original
}

\section{Anti-CagA Antibodies in Peptic Ulcer Patients Infected with Helicobacter pylori}

\author{
Tatsuo Ozawa, Nozomi Yoshikawa, Fuyuhiko Yamamura, \\ Yasushi Akita and Keiji Mitamura
}

\begin{abstract}
We investigated the clinical significance of serum anti-CagA antibody in peptic ulcer patients infected with Helicobacter pylori and assessed its association with histologic changes in gastric mucosa. The subjects were 62 Japanese patients with $H$. pylori infection and endoscopically diagnosed peptic ulcers (24 men and 19 women with gastric ulcers and 14 men and 5 women with duodenal ulcers). Serum samples were assayed for the presence of antibodies to CagA with an enzyme-linked immunosorbent assay procedure. The $\operatorname{cag} A$ gene was assayed in the gastric juice of 42 of the 62 patients. Histologic examinations were performed according to the histologic classification of the Updated Sydney System. Serum anti-CagA antibody was detected in $76.7 \%$ of patients with gastric ulcer and in $73.7 \%$ of those with duodenal ulcer. Among the patients with duodenal ulcers, the scores of chronic inflammatory cell infiltration were significantly higher in seropositive patients than in seronegative patients $(P=.020)$. Serum titers of anti-CagA antibody correlated with scores of chronic inflammatory cell infiltration $(r=0.525, P=$ 0.026). The cagA gene of $H$. pylori was detected in the gastric juice of 28 of 29 patients with gastric ulcers and all in 13 patients with duodenal ulcers. The absence of anti-CagA antibody in the serum does not necessarily reflect the absence of the cagA gene of $H$. pylori. However, serum titers of anti-CagA antibodies correlated with chronic inflammatory cell infiltration into the gastric mucosa of the duodenal ulcer patients. This may indicate that infection with cagA-positive strains of $H$. pylori is associated with chronic inflammation in the gastric mucosa of Japanese patients with duodenal ulcers.
\end{abstract}

Key words : serum anti-CagA antibody, chronic inflammatory cell infiltration, peptic ulcer, Helicobacter pylori

\section{Introduction}

Helicobacter pylori $(\boldsymbol{H}$. pylori) is now considered a central factor in the pathogenesis of peptic ulcers. A vacuolating cytotoxin and a $H$. pylori protein with a molecular weight of approximately $128 \mathrm{kd}$ were discovered in the supernatant of cultured $H$. pylori ${ }^{1)}$. The gene encoding the protein was found to be closely associated with the vacuolating cytotoxin and was named the cytotoxin-associated gene $\mathrm{A}(\operatorname{cag} A)^{2)}$. The CagA protein stimulates production of interleukin-8 (IL-8) by cultured human gastric cancer cells ${ }^{3)}$. Moreover, $H$. pylori

Second Department of Internal Medicine, Showa University School of Medicine, 1-5-8 Hatanodai, Shinagawa-ku, Tokyo 142-8666, Japan. 
expressing CagA stimulates IL-8 production via gastric epithelial cells in vitro, and neutrophil cells induced by $H$. pylori injure the gastric mucosa ${ }^{4}$. On the other hand, serum titers of an antibody against the $128 \mathrm{kd}$ protein are significantly higher in patients with gastric cancer ${ }^{5)}$. In a series of Western blotting tests conducted in Japan, high percentages of patients with $H$. pylori were seropositive for anti-CagA antibody regardless of whether they had peptic ulcers ${ }^{6}$. In a series of patients from a North American population, neither peptic ulcers nor asymptomatic $H$. pylori gastritis were correlated with serum anti-CagA antibodies $^{7)}$. In Japan, patients with gastric ulcers outnumber those with duodenal ulcers. Mucosal atrophy of the gastric corpus may be more severe in Japanese patients than in Western patients because of the high prevalence of $H$. pylori infection. In the present study, we investigated the clinical significance of anti-CagA antibodies in peptic ulcer patients infected with $H$. pylori and assessed the association of anti-CagA antibody with histologic changes in gastric mucosa.

\section{Materials and Methods}

\section{Subjects}

The subjects were 62 patients with $H$. pylori infection and endoscopically diagnosed gastric ulcers ( 24 men and 19 women, mean age $55.1 \pm 2.1$ years) and duodenal ulcers (14 men and 5 women, mean age $42.4 \pm 3.7$ years) treated at Showa University Hospital from January 1996 to January 2000. These were patients who had given consent for detailed analysis of any $H$. pylori infection. The subjects were treated with $\mathrm{H}_{2}$-receptor antagonists or proton pump inhibitors. The examinations were performed within a week of start of treatment. None of the subjects had undergone eradication therapy for $\boldsymbol{H}$. pylori or long-term treatments with antibiotics or nonsteroidal anti-inflammatory drugs (Table 1). The protocol was approved by the ethics committee of Showa University Hospital. Informed consent was obtained from all subjects.

\section{Endoscopies and Histologic examinations}

Gastroduodenal examinations were performed with a gastroduodenoscope (Q20, Q30, Q200, or Q240, Olympus; Tokyo, Japan) that had been washed in an automatic endoscope washer. Three samples of mucosa were obtained with disposable biopsy forceps (Scientific Corporation, Boston, MA, USA) from both the gastric antrum and corpus on the greater curvature. The biopsy specimens were taken from areas of mucosa distant from any focal lesions. One specimen was cultured on blood agar medium in a microaerophilic environment, the second was used for polymerase chain reaction (PCR) assay, and the third examined microscopically (hematoxylin-eosin stain and Giemsa stain). The PCR assays

Table 1. Demographics and clinical characteristics of patients

\begin{tabular}{|c|c|c|c|c|c|c|}
\hline \multirow{2}{*}{ Anti-CagA antibody } & \multicolumn{3}{|c|}{ Gastric Ulcer $(N=43)$} & \multicolumn{3}{|c|}{ Duodenal Ulcer $(N=19)$} \\
\hline & positive & negative & $\mathrm{p}$ values & positive & negative & $p$ values \\
\hline Sex $($ male/female $)$ & $16 / 17$ & $8 / 2$ & 0.88 & $10 / 4$ & $4 / 1$ & $>0.99$ \\
\hline Age & $53 \pm 2$ & $62 \pm 4$ & 0.08 & $45 \pm 5$ & $36 \pm 4$ & 0.14 \\
\hline CagA Titers & $69.6 \pm 12.0$ & & & $82.0 \pm 19.9$ & & \\
\hline Hp-IgA Titers & $389.2 \pm 41.4$ & $369.4 \pm 73.0$ & 0.82 & $304.2 \pm 66.3$ & $174.4 \pm 63.9$ & 0.18 \\
\hline
\end{tabular}


were performed as per the method of Valentine et $\mathrm{al}^{8)}$ using a pair of primers that amplified a 1.9-kb fragment of $\boldsymbol{H}$. pylori genomic DNA. Histologic examinations were performed according to the histologic classification of the Updated Sydney System ${ }^{9}$.

Anti-H. pylori antibody and H. pylori PCR assay

Serum samples of patients were examined for anti- $H$. pylori immunoglobulin G (IgG) with an $H$. pylori enzyme immunoassay kit (AMRAD, Kew, Victoria, Australia) ${ }^{10)}$. The results are expressed quantitatively, and a titer of less than $30 \mathrm{U} / \mathrm{ml}$ was considered negative. To confirm $H$. pylori infection, positive results were required from at least two of the following tests: culture, microscopic examination, PCR assay and $H$. pylori serum enzyme immunoassay.

\section{Anti-CagA antibodies}

Serum samples were stored at $-80^{\circ} \mathrm{C}$ and assayed for the presence of antibodies to CagA with an enzyme-linked immunosorbent assay procedure (Radim, Pomezia, Italy) ${ }^{11)}$. Serum was considered IgG-positive if the concentration was 15 Radim units (UR) per $\mathrm{ml}$ or more.

\section{cagA gene in gastric juice}

The cagA gene in gastric juice was assayed in 42 of the 62 patients. Gastric juice samples were not taken from the remaining 20 patients. Gastric juices were pulled through a suction tube at endoscopic examinations and stored at $-80^{\circ} \mathrm{C}$. A new suction tube was used for each sample. Approximately $1 \mathrm{ml}$ of gastric juice was neutralized with $1 \mathrm{~N} \mathrm{NaOH}$ and centrifuged at $15000 \mathrm{rpm}$ for 10 minutes. The pellet was resuspended in $0.5 \mathrm{ml}$ of tissue extraction buffer, and the DNA was extracted. The $H$. pylori DNA was amplified with a primer pair for cagA as described by Tummuru et $\mathrm{al}^{2}{ }^{2}$. Nested PCR was used to detect cagA: first primer pair, 5'-(GATAACAGGCAAGCTTTTGAGG)-3' (sense) and 5'-(CTGCAA AAGATTGTTTGGCAGA)-3' (antisense); second primer pair, 5'-(AGGGAAGAATACTC CAATAAAGCGA)-3' (sense) and 5' (CTGCAAAAGATTGTTTGGCAGA)-3' (antisense). The PCR conditions were denaturation at $94^{\circ} \mathrm{C}$ for 30 seconds, annealing at $55^{\circ} \mathrm{C}$ for 1.0 minute, and extension at $72^{\circ} \mathrm{C}$ for 1.0 minute ( 40 cycles). The amplified products were electrophoresed on a 3.0\% agarose gel and stained with ethidium bromide. The primary PCR resulted in a 349 bp fragment and the nested PCR in a 313 bp fragment.

\section{Statistical analysis}

Data were analyzed with the Student's $t$-test, the Mann-Whitney $U$ test, and the Fisher exact test. Correlations between titers of serum anti-CagA antibody and scores of chronic inflammation were examined with the Spearman rank correlation test. Differences with a $P$ value less than .05 were considered statistically significant. All $P$ values are two-tailed.

\section{Results}

Serum anti-CagA antibody was detected in $76.7 \%$ of patients with gastric ulcers and in 73.7\% of those with duodenal ulcers. Among patients with gastric ulcers, the histologic features did not differ significantly between anti-CagA seropositive and seronegative patients (Fig. 1). Among patients with duodenal ulcers, there were no significant differences between the anti-CagA seropositive and seronegative patients in terms of $\boldsymbol{H}$. pylori density, 


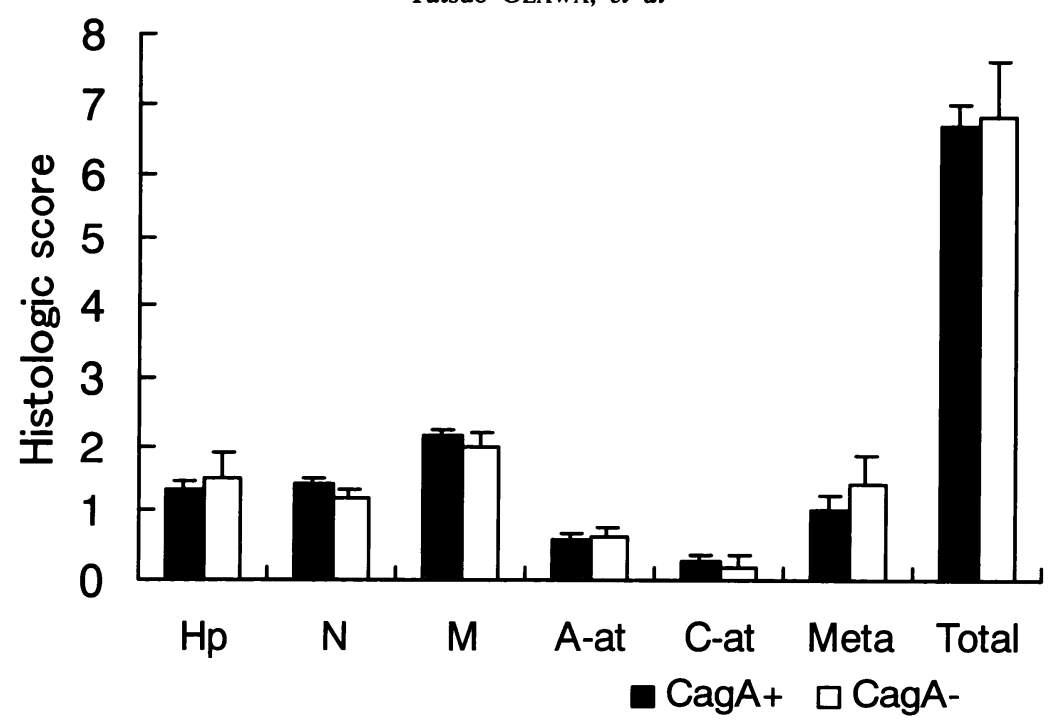

Fig. 1. Histologic comparison of gastric ulcer patients infected with $H$. pylori who were anti-CagA seropositive or seronegative. Hp, $H$. pylori density, $P=.674 ; \mathrm{N}$, polymorphonuclear neutrophil activity, $P=.204$; $M$, chronic inflammation, $P=.495$; A-at, atrophy of gastric antrum, $P=.893$; C-at, atrophy of gastric corpus, $P=.671$; Meta, intestinal metaplasia, $P=.431 ; \mathrm{T}$, Total scores, $P=.838$.

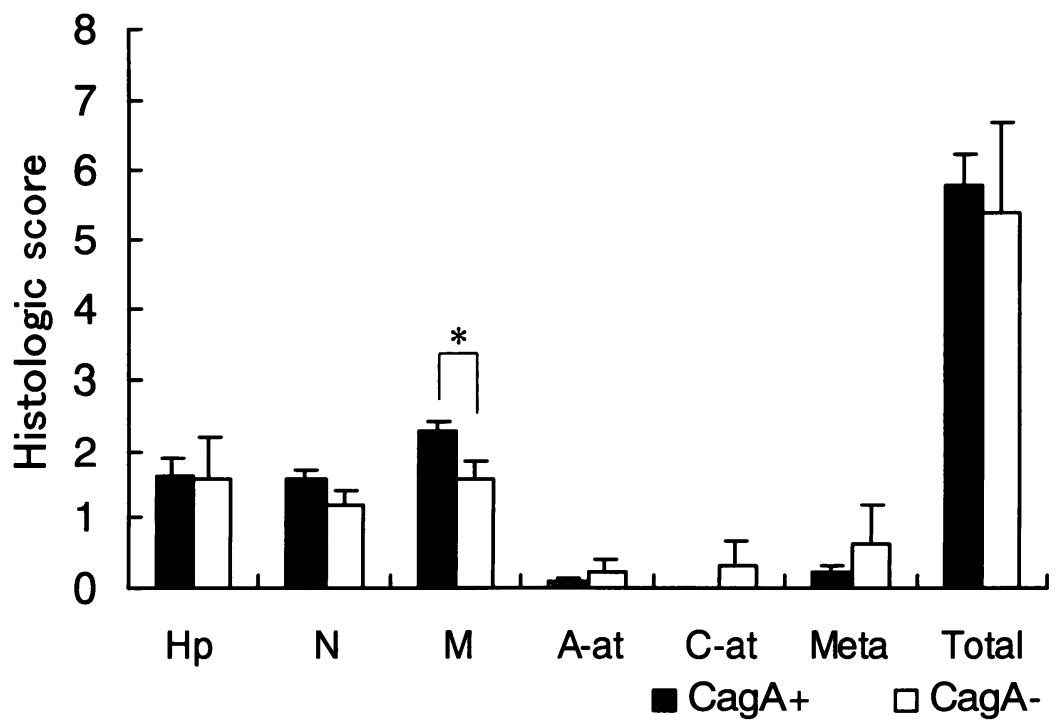

Fig. 2. Histologic comparison of duodenal ulcer patients infected with $H$. pylori who were anti-CagA seropositive or seronegative. $\mathrm{Hp}, P=.884 ; \mathrm{N}, P=.165 ; \mathrm{M}, P=.020 *$; A-at, $P=.434$; C-at, $P=.056$; Meta, $P=.896$; Total, $P=.815$.

polymorphonuclear neutrophil activity, glandular atrophy of the antrum or corpus, or intestinal metaplasia. However, scores of chronic inflammatory cell infiltration were significantly higher in seropositive patients than in seronegative patients $(P=.020)$ (Fig. 2$)$. Serum titers of anti-CagA antibody correlated with scores of chronic inflammatory cell 


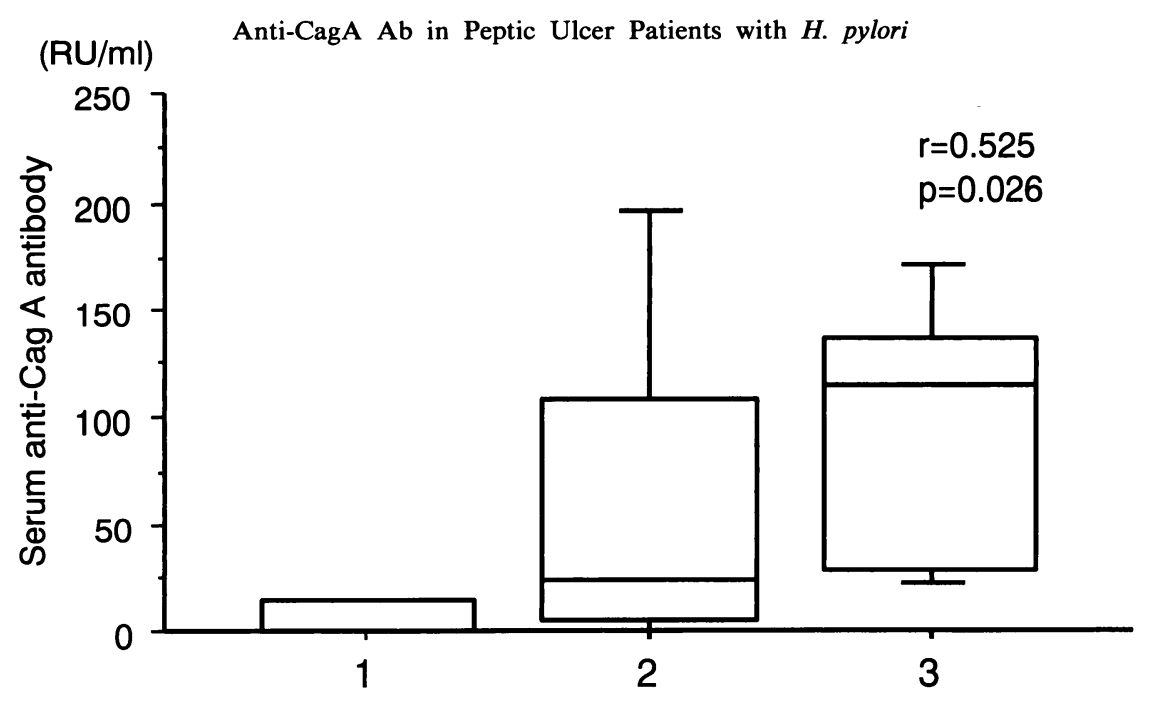

Fig. 3. Correlation between serum titers of anti-CagA antibody and scores of chronic inflammatory cell infiltration.

Table 2. The results of gastric juice $\operatorname{cag} A$ PCR assay and serum anti-CagA antibody status

\begin{tabular}{llccccc}
\hline & \multirow{2}{*}{ Gastric juice } & \multicolumn{2}{c}{ Gastric Ulcer $(\mathrm{N}=29)$} & \multicolumn{2}{c}{ Duodenal Ulcer $(\mathrm{N}=13)$} \\
\cline { 3 - 6 } & & $\operatorname{cag} A+$ & $\operatorname{cag} A-$ & cagA & cagA- \\
\hline Anti-CagA & seropositive & 21 & 1 & 10 & 0 \\
antibody & seronegative & 7 & 0 & 3 & 0 \\
\hline
\end{tabular}

infiltration (titers in patients seronegative for anti-CagA antibodies were regarded as zero) $(r=.525, P=.026)$ (Fig. 3). The cagA gene of $H$. pylori was detected in the gastric juice of 28 of 29 patients with gastric ulcers and in all 13 patients with duodenal ulcers. Moreover, the cagA gene of $H$. pylori was found in the gastric juice of all patients seronegative for anti-CagA antibodies ( 7 with gastric ulcers and 3 with duodenal ulcers) (Table 2).

\section{Discussion}

Several factors, such as cytotoxins induced by $H$. pylori, cytokines induced by acute or chronic inflammatory cells, and the immune response of infected subjects, contribute to the gastric mucosal damage ${ }^{3,12,13)}$. The CagA protein induced by $H$. pylori is closely associated with gastroduodenal diseases ${ }^{5,14,15)}$. Nevertheless, the significance of the serum anti-CagA antibody is poorly understood. The rate of seropositivity for anti-CagA antibody is higher in patients with peptic ulcers than in patients with non-ulcer dyspepsia. ${ }^{16,17)}$. Also, the CagA-positive strain of $H$. pylori is associated with IL-8 induction in gastric epithelium ${ }^{4,18)}$. Moreover, the picB gene of $H$. pylori plays a role in the induction of IL-8 in gastric epithelial cells ${ }^{19)}$.

In the present study, immunoenzymatic assay showed that the seropositivity for anti-CagA antibody in patients with duodenal ulcers was associated with chronic inflammatory cell infiltration, but was not associated with the scores of $H$. pylori density, 
polymorphoneutrophilic cell infiltration, glandular atrophy of antrum or corpus, or intestinal metaplasia. Furthermore, no relationship was found between seropositivity for anti-CagA antibody and histologic scores in patients with gastric ulcers. The previous studies have failed to find any correlation of histologic findings and IgG antibody for CagA protein in patients with peptic ulcers or asymptomatic $H$. pylori gastritis. In fact, the only histologic difference that has been found on the basis of anti-CagA antibody has been mononuclear cell infiltration of the gastric antrum ${ }^{7)}$. Moreover, serologic tests were less accurate than PCR for determining the CagA status of $H$. pylori strains ${ }^{20)}$. In the present study, 28 of the 29 patients with gastric ulcers were positive for the cagA gene. The 1 patient negative for the $\operatorname{cag} A$ gene was seropositive for anti-CagA antibody. The $\operatorname{cag} A$ gene was found in the gastric juice of all 13 patients with duodenal ulcers. Together, these results suggested that the absence in serum of anti-CagA antibody did not necessarily reflect the absence of the cagA gene of $H$. pylori.

Inflammatory responses have been reported to be associated with the $\operatorname{cagA}$ gene $^{21,22)}$. Therefore, we investigated the correlation between serum titers of anti-CagA antibody and histologic scores in peptic ulcer patients infected with $H$. pylori. In patients with duodenal ulcers, serum titers of anti-CagA antibody correlated positively with scores of chronic inflammatory cell infiltration. However in patients with gastric ulcers, the scores of histologic features did not correlate with serum titers of anti-CagA antibody. Western blotting has shown that the rate of seropositivity for CagA antibody is high in Japanese patients with $H$. pylori infection, irrespective of the presence of a peptic ulcer ${ }^{6)}$. Our results of seropositivity for $\operatorname{Cag} A$ antibody were less than the previously reported results, which may be due to the decreased sensitivity of assaying $\operatorname{Cag} A$ protein in gastric juice samples by ELISA as compared to Western blotting analysis ${ }^{17)}$. Furthermore, most Japanese $\boldsymbol{H}$. pylori strains have an intact cag pathogenicity island ${ }^{23)}$. The present histologic examination showed a positive correlation between serum titers of anti-CagA antibody and the severity of chronic inflammatory cell infiltration into the gastric epithelium in patients with duodenal ulcers, but showed no correlation in patients with gastric ulcers. The differing results between patients with gastric ulcers and those with duodenal ulcers may be due to atrophy and intestinal metaplasia of the gastric mucosa, because the mucosal atrophy in the gastric antrum or corpus in patients with gastric ulcers is much more severe than in patients with duodenal ulcers. We found that the scores of intestinal metaplasia and glandular atrophy in the gastric antrum were significantly higher in patients with gastric ulcers than in patients with duodenal ulcers. Scores of glandular atrophy were also slightly but not significantly higher in the gastric corpus. The number of inflammatory cells and lymphoid follicles is lower in intestinalized mucosa than in non-intestinalized gastric mucosa ${ }^{24)}$. In patients with gastric ulcers, the grade of atrophy in gastric mucosa may not correlate with chronic inflammatory cell infiltration. Therefore, the presence in serum of anti-CagA antibodies was not associated with chronic inflammatory cell infiltration in patients with gastric ulcers.

In conclusion, the absence of serum anti-CagA antibodies does not necessarily reflect the absence of the cagA gene of $\boldsymbol{H}$. pylori. However, serum titers of anti-CagA antibodies correlated with chronic inflammatory cell infiltration into the gastric mucosa of Japanese duodenal ulcer patients. This may indicate that infection with $\operatorname{cag} A$-positive strains of $H$. pylori is associated with chronic inflammation in the gastric mucosa of Japanese patients 
with duodenal ulcers.

\section{Acknowledements}

We thank Dr Y. Ashiwara of Mitsubishi Kagaku Bioclinical Laboratories for the detection of serum anti-CagA antibody and cagA gene of $H$. pylori.

\section{References}

1) Cover TL and Blaser MJ : Purification and characterization of the vacuolating toxin from Helicobacter pylori. J Biol Chem 267 : 10570-10575 (1992)

2) Tummuru MKR, Cover TL and Blaser MJ : Cloning and expression of a high-molecular-mass major antigen of Helicobacter pylori : evidence of linkage to cytotoxin production. Infect Immun 61 : 1799-1809 (1993)

3) Crabtree JE, Wyatt JI, Trejdosiewicz LK, Peichl P, Nichols PH, Ramsay N, Primrose JN and Lindley IJD : Interleukin-8 expression in Helicobacter pylori infected, normal, and neoplastic gastroduodenal mucosa. $J$ Clin Pathol 47 : 61-66 (1994)

4) Crabtree JE, Covacci A, Farmery SM, Xiang Z, Tompkins DS, Perry S, Lindley IJD and Rappuoli R: Helicobacter pylori induced interleukin-8 expression in gastric epithelial cells is associated with CagA positive phenotype. J Clin Pathol 48 : 41-45 (1995)

5) Crabtree JE, Wyatt JI, Sobala GM, Miller G, Tompkins DS, Primrose JN and Morgan AG: Systemic and mucosal humoral responses to Helicobacter pylori in gastric cancer. Gut 34 : 1339-1343 (1993)

6) Maeda S, Kanai F, Ogura K, Yoshida H, Ikenoue T, Takahashi M, Kawabe T, Shiratori Y and Omata M: High seropositivity of anti-CagA antibody in Helicobacter pylori-infected patients irrelevant to peptic ulcers and normal mucosa in Japan. Dig Dis Sci 42 : 1841-1847 (1997)

7) Graham DY, Genta RM, Graham DP and Crabtree JE : Serum CagA antibodies in asymptomatic subjects and patients with peptic ulcer: lack of correlation of IgG antibody in patients with peptic ulcer or asymptomatic Helicobacter pylori gastritis. J Clin Pathol 49 : 829-832 (1996)

8) Valentine JL, Arthur RR, Mobley HLT and Dick JD : Detection of Helicobacter pylori by using the polymerase chain reaction. J Clin Microbiol 29 : 689-695 (1991)

9) Dixon MF, Genta RM, Yardley JH and Correa P : Classification and grading of gastritis: The Updated Sydney System. Am J Surg Pathol 20 : 1161-1181 (1996)

10) Schembri MA, Lin SK and Lambert JR: Comparison of commercial diagnostic tests for Helicobacter pylori antibodies. J Clin Microbiol 31 : 2621-2624 (1993)

11) Navaglia F, Basso D, Piva MG, Brigato L, Stefani A, Dal Bo N, Mario FD, Rugge M and Plebani M: Helicobacter pylori cytotoxic genotype is associated with peptic ulcer and influences serology. Am $J$ Gastroenterol 93 : 227-230 (1998)

12) Correa P: Human gastric carcinogenesis : A multistep and multifactorial process-first American Cancer Society award lecture on cancer epidemiology and prevention. Cancer Res 52:6735-6740 (1992)

13) Negrini R, Lisato L, Zanella I, Cavazzini L, Gullini S, Villanacci V, Poiesi C, Albertini A and Ghielmi S : Helicobacter pylori infection induces antibodies cross-reacting with human gastric mucosa. Gastroenterology 101 : 437-445 (1991)

14) Covacci A, Censini S, Bugnoli M, Petracca R, Burroni D, Macchia G, Massone A, Papini E, Xiang Z, Figura $\mathrm{N}$ and Rappuoli R : Molecular characterization of the $128-\mathrm{kDa}$ immunodominant antigen of Helicobacter pylori associated cytotoxicity and duodenal ulcer. Proc Natl Acad Sci USA 90 : 5791-5795 (1993)

15) Shimoyama T, Fukuda S, Tanaka M, Mikami T, Munakata A and Crabtree JE : CagA seropositivity associated with development of gastric cancer in Japanese population. J Clin Pathol 51 : 225-228 (1998)

16) Ching CK, Wong BCY, Kwok E, Ong L, Covacci A and Lam SK : Prevalence of CagA-bearing Helicobacter pylori strains detected by the anti-CagA assay with peptic ulcer disease and in controls. Am J Gastroenterol 91 : 949-953 (1996)

17) Cover TL, Glupczynski Y, Lage AP, Burette A, Tummuru MK, Perez PG, Perez-perez GI and Blaser MJ : Serologic detection of infection with cagA ${ }^{+}$Helicobacter pylori strains. J Clin Microbiol 33 : 1496-1500 (1995)

18) Sharma SA, Tummuru MKR, Miller GG and Blaser MJ : Interleukin-8 response of gastric epithelial cell lines to Helicobacter pylori stimulation in vitro. Infect Immun $63: 1681-1687$ (1995)

19) Tummuru MKR, Sharma SA and Blaser MJ : Helicobacter pylori picB, a homologue of the Bordetella pertussis toxin secretion protein, is required for induction of IL-8 in gastric epithelial cells. Mol Microbiol 18 : 867-876 (1995)

20) Yamaoka Y, Kodama T, Graham DY and Kashima K : Comparison of serological tests to determine the CagA or VacA status of Helicobacter pylori strains. J Clin Microbiol 36 : 3433-3434 (1998)

21) Peek RM Jr, Miller GG, Tham KT, Perez-Perez GI, Zhao X, Atherton JC and Blaser MJ : Heightened 
inflammatory response and cytokine expression in vivo to cagA ${ }^{+}$Helicobacter pylori strains. Lab Invest 71 : 760-770 (1995)

22) Gunn MC, Stephens JC, Stewart JAD, Rathbone BJ and West KP: The significance of cagA and vacA subtypes of Helicobacter pylori in the pathogenesis of inflammation and peptic ulceration. J Clin Pathol $\mathbf{5 1}$ : 761-764 (1998)

23) Maeda S, Yoshida $\mathrm{H}$, Ikenoue $\mathrm{T}$, Ogura $\mathrm{K}$, Kanai $\mathrm{F}$ and Kato $\mathrm{N}$ : Structure of cag pathogenicity island in Japanese Helicobacter pylori isolates. Gut 44 : 336-341 (1999)

24) Tsutsumi $Y$, Nagura $H$ and Watanabe $K$ : Immune aspects of intestinal metaplasia of the stomach: an immunohistochemical study. Virchows Arch A Pathol Anat 403 : 345-359 (1984)

[Received October 16, 2002 : Accepted November 22, 2002] 